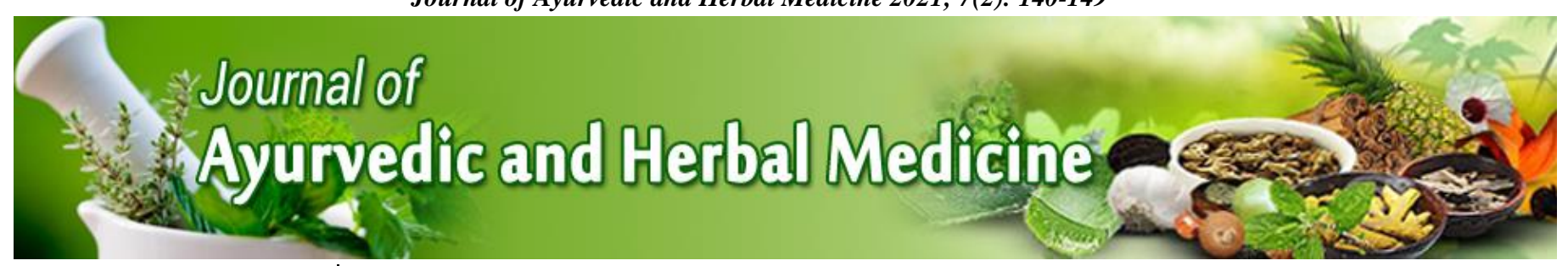

\section{Review Article}

ISSN: 2454-5023

J. Ayu. Herb. Med.

2021; 7(2): 140-149

Received: 25-03-2021

Accepted: 27-05-2021

(C) 2021, All rights reserved www.ayurvedjournal.com DOI: $10.31254 /$ jahm.2021.7213

\title{
Lepidium sativum: A potential functional food
}

\author{
Mamta B. Shah ${ }^{1}$, Vinisha A. Dudhat ${ }^{1}, K_{\text {Krupa V. Gadhvi }}$
}

1 Department of Pharmacognosy and Phytochemistry, L. M. College of Pharmacy, Ahmedabad, Gujarat, India

\section{ABSTRACT}

Lepidium sativum Linn. (family Cruciferae) is an edible herb that is botanically related to watercress and mustard, having their peppery, tangy taste and odour. Traditionally L. sativum seeds are used to treat wounds, sprains, asthma, bronchitis, cough and is considered useful as abortifacient, aphrodisiac, antibacterial, diuretic, expectorant, gastrointestinal stimulant, gastroprotective, laxative and stomachic. Many of these traditional uses have been scientifically validated using different in vitro and in vivo studies and in this review are compiled in an inclusive manner. Seeds are reported to be rich in carbohydrates, vitamins, amino acids, proteins, triterpenoids, steroids and saponin glycosides possessing different pharmacological activities. Aim of the study: This study is an effort to collate complete scientific literature published till March 2021 in order to generate a succinct summation on the distribution, traditional beneficial potential, chemical constituents, phytochemistry, pharmacology and toxicology of this coveted species of genus Lepidium. Materials and Methods: Exploring assorted scientific databases. Results: The present methodically compiled review article accentuates medicinal and nutritional significance of this highly valued plant by focusing on various aspects of the plant such as the, physicochemical characterisation and pharmacological studies that validates folklore uses. Thus, this annotated script on L. sativum would be a handy tool to explore the future prospective of research on this traditional plant.

Keywords: Cruciferae, Garden cress, L. sativum, Pharmacology, Phytochemistry.

\section{INTRODUCTION}

L. sativum Linn. (Family Cruciferae) is an annual, glabrous, erect, and fast-growing, herb commonly known as "common cress," "garden cress," "garden pepperweed," "chandrashoor," "raktbija", "aseliyo" and many more. The plant is native to Europe and southwestern Asia, introduced and cultivated throughout India, Europe, United States, England, France, Asia, etc. as a salad plant ${ }^{[1-3]}$. All parts are of commercial value, but it is cultivated throughout the world mainly for its seeds and leaves of which the later are consumed as salad for piquant flavour ${ }^{[4,5]}$. The plant is also used in poultices for wounds and sprains ${ }^{[6]}$. Seeds are used to treat respiratory diseases like asthma [7-9] bronchitis and cough [7-9], bleeding piles [10], scorbutic diseases [11], liver complaints [12-18], Root is specifically valued in the treatment of secondary syphilis and tenesmus ${ }^{[19]}$.

Documented records on phytochemical aspects revealed that raw seeds in particular are rich in vitamins A, C, and K; minerals, carbohydrates, dietary fibres, protein, and fat ${ }^{[20-23]}$.

L. sativum is also known for its several pharmacological actions such as anti-bacterial [6, 24-31], anti carcinogenic [32-39], anti-inflammatory [6, 30, 40-45], cardioprotective, antioxidant [11, 30, 46-51], hypolipidemic [16, $17,40,52-58]$, diuretic ${ }^{[59-61]}$, gastro-protective ${ }^{[62-67]}$, stomachic ${ }^{[62,64,65,68]}$, gastrointestinal stimulant ${ }^{[62-67]}$, and laxative ${ }^{[67]}$ and many more.

The present review is an assemblage of literature on identification, traditional uses, phytochemical and pharmacological research work on L. sativum, that explicate the all-round medicinal utilities of this plant.

*Corresponding author:

\section{Mamta B. Shah}

Professor \& Head, Department of

Pharmacognosy

and

Phytochemistry, L. M. College of Pharmacy, Ahmedabad, Gujarat, India

Email: mbshah2007[at]rediffmail.com

\section{HABITAT}

L. sativum can be grown all over around the year at all altitudes but the most favourable season is winter. Cultivation is done on both mass scales and individual scales and it is suitable for hydroponic cultivation also and can thrive well in slightly alkaline water $[4,5]$. 


\section{DISTRIBUTION}

\section{Global distribution}

L. sativum is native of Egypt and Southwest Asia that as a naturalised or more frequently casual plant is widespread in Asia, Afghanistan, Bhutan, China, India, Japan, Kazakhstan, Kyrgyzstan, Nepal, Pakistan, Russia, Tajikistan, Turkmenistan, Uzbekistan, Vietnam; Africa; Europe; North America; South America ${ }^{[69]}$.

\section{Local distribution}

It is found to be growing throughout India in cultivated fields, gardens, roadsides and near railway tracks, at an altitude up to $2000 \mathrm{~m}^{[10]}$.

\section{Morphology and microscopy}

L. sativum is an annual edible herb $15-50 \mathrm{~cm}$ in height, straight, branched, glabrous, rarely pilose with pinnatisect basal leaves that are 5-10 cm long, 2.5-3.5 cm broad, stalked to subsessile, while cauline leaves are linear and sessile with entire margin as shown in Fig. 1. Racemes are much-branched, each 20-40 flowered, ebracteate. Flowers are small about $3 \mathrm{~mm}$ in size, white or pinkish; Fruit is on suberect to ascending pedicel that is appressed to rachis and 5 to 6.4 $\mathrm{mm}$ in size. It is obovate or broadly elliptic, emarginated, apically broadly winged with apical notch 0.2 to $0.8 \mathrm{~mm}$ deep. Seeds are ovateoblong, 3 lobed, $3 \mathrm{~mm}$ long, $1 \mathrm{~mm}$ broad, brownish-red in colour as shown in Fig. 2.

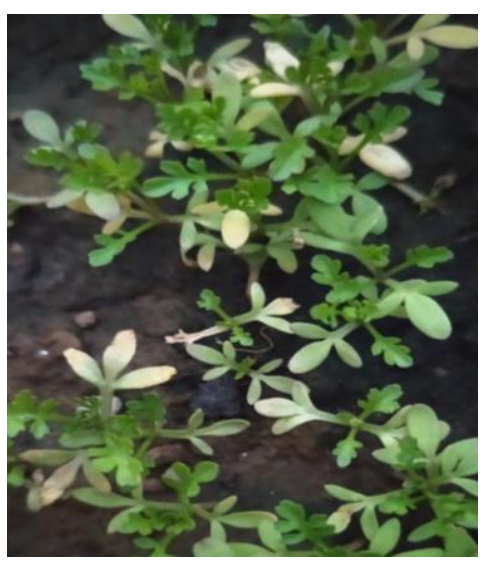

Figure 1: Leaf of Lepidium sativum

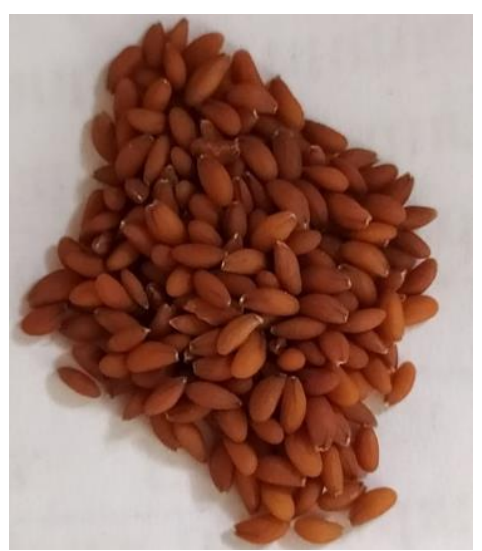

Figure 2: Seeds of Lepidium sativum

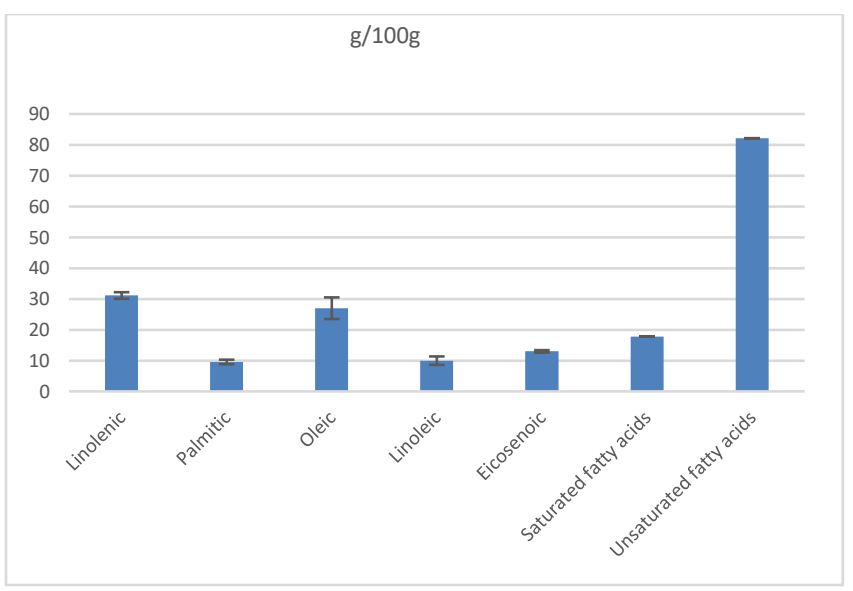

Figure 3: \% Major Fatty acids

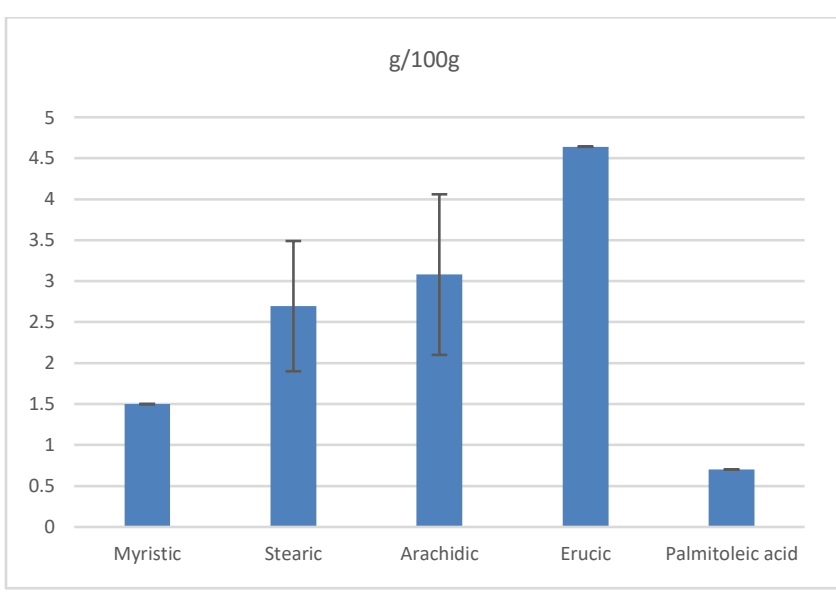

Figure 4: \%Minor Fatty acids

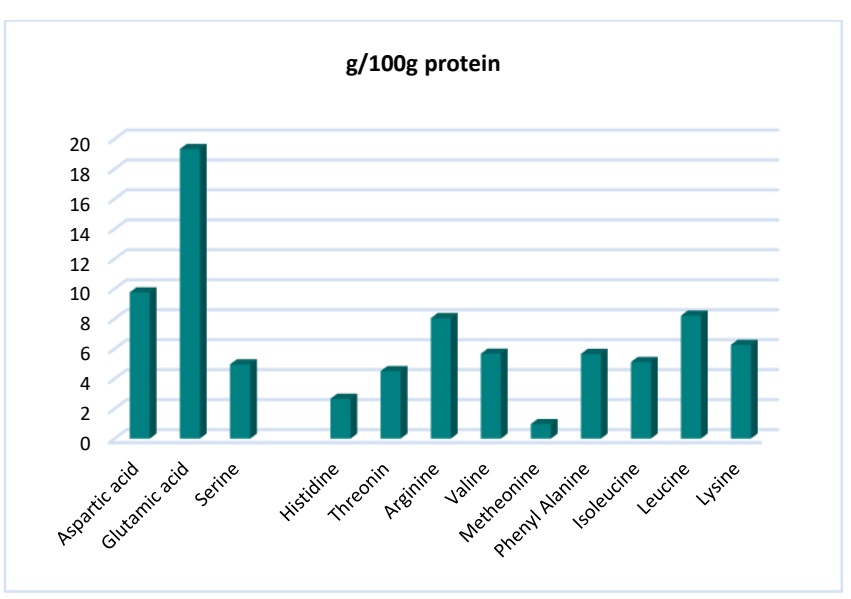

Figure 5: \% Amino acids

\section{Traditional use}

L. sativum has been traditionally used for many diseases such as cold infusion of seed is used in treatment of high cough, spleen and liver chronic enlargement, flatulence, diarrhoea, dysentery, indigestion, rheumatic pain, inflammation, viscous humours, tenesmus, secondary syphilis, abortion, anaemia and weakness [70-72]. For sprains, dysentery, leprosy, skin diseases they are mostly used as poultices. The seeds are also recommended as depurative, tonic, aphrodisiac, hemogenic, galactagogue and diuretic. Moreover seeds are useful in preventing the hair loss and stimulating the appetite ${ }^{[73]}$. 
L. sativum is noted to relieve the body's allergic responses to insect bites. According to Ayurvedic system of medicine it exhibits hot, bitter, tonic, and aphrodisiac properties $[4,3,74-76]$.

\section{Other uses}

Recently, L. sativum is getting recognition as a functional food. As it has high nutritive value, people consume it as a dietary supplement. In some of the countries, noodles [77], biscuits ${ }^{[78]}$, health drinks ${ }^{[79]}$, flakes ${ }^{[80]}$, cereals [81], ladoo [82, 83, 72], snacks ${ }^{[84]}$, instant 'dhokla' mix [85], and nutricookies [86], prepared from the seeds are marketed. Leaf of $L$. sativum used in salad preparation because of its tangy taste and health benefit [22, 69,73, 87-92]. Seeds serve a source of mucilage that is used as pharmaceutical excipients [22, 93, 94].

Seed cake of $L$. sativum is also used as a water purifying bed. Also seeds have the capacity to absorb heavy metals from the soil and so are used as soil purifier for their removal of from the soil $[95,96]$.

\section{Phytochemistry}

L. sativum is known for its various activities since ancient time and recently seeds in particular are being popularly promoted as functional food too. The seeds are rich in minerals, vitamins, essential fatty acids. protein, amino acids and flavonoids, alkaloids, saponins.

\section{Basic component}

Basic nutrient like total carbohydrate, protein, moisture content, and ash value of $L$. sativum is mentioned in Table $1^{[4,20-23]}$.

Table 1: Basic components of $L$. sativum

\begin{tabular}{|l|l|}
\hline Parameter & \% w/w $\mathbf{~ S D}$ \\
\hline Moisture & $5.70 \pm 1.71$ \\
\hline Protein & $22.6 \pm 2.32$ \\
\hline Ash & $5.14 \pm 0.49$ \\
\hline Crude fibre & $8.21 \pm 1.85$ \\
\hline Carbohydrates & $34.23 \pm 4.71$ \\
\hline Fat & $24.82 \pm 2.66$ \\
\hline oil & 22.66 \\
\hline
\end{tabular}

\section{Vitamins}

Vitamins are essential in our day to day life. Some evidences confirm the presence of vitamins in L. sativum as mentioned in Table 2 [20, 97, 98].

Table 2: Vitamins obtained from L. Sativum

\begin{tabular}{|l|l|}
\hline Vitamins & $\%$ daily value \\
\hline Vitamin A & $138 \%$ \\
\hline Vitamin C & $115 \%$ \\
\hline Vitamin D & $0 \%$ \\
\hline Vitamin B-6 & $10 \%$ \\
\hline Cobalamin & $0 \%$ \\
\hline
\end{tabular}

\section{Minerals}

Minerals are those elements which are required for our body development and function normally. L. sativum is reach in minerals Table 3 [4, 20-23, 97-99].

Table 3: Mineral content of L. sativum

\begin{tabular}{|l|l|}
\hline Mineral Content & \% DWB \pm SD \\
\hline Iron (Fe) & $0.04 \pm 0.02$ \\
\hline Copper (Cu) & $0.01 \pm 0.02$ \\
\hline Zinc (Zn) & $0.01 \pm 0.02$ \\
\hline Manganese (Mn) & $0.01 \pm 0.008$ \\
\hline Boron (B) & 0.01 \\
\hline Molybdenum (Mb) & 0.004 \\
\hline Aluminium (Al) & 0.02 \\
\hline Potassium (K) & $4.63 \pm 5.16$ \\
\hline Phosphorus (P) & $2.87 \pm 2.62$ \\
\hline Calcium (Ca) & $1.16 \pm 1.26$ \\
\hline Sodium (Na) & $0.13 \pm 0.08$ \\
\hline Magnesium (Mg) & $1.73 \pm 1.42$ \\
\hline Sulphur(S) & 2.93 \\
\hline
\end{tabular}

\section{Essential fatty acids}

L. sativum serves as a potential source of fatty acids, some essential fatty acids are ethyl linolate; ethyl octadecenoate and many more and their diagrammatical representation is given in Fig. 3 and Fig. 4 [20, 22, 97, $101,102]$.

\section{Saturated fatty acids and its derivative}

L. sativum is reported to contain $n$-hexadecanoic acid, hexadecanoic acid ethyl ester, glycidyl palmitate; ethyl (E)-octadec-9-enoate; ethyl icosanoate; $\quad$ glycidyl Oleate; 1,3-dihydroxypropan-2-yl hexadecanoate, dodecanoic acid, ethyl pentadecanoate, tetradecanoic acid, ethyl tetradecanoate; pentadecanoic acid, ethyl pentadecanoate, pentadecanoic acid, 6,10,14-trimethylpentadecan-2-one, pentadecanoic acid ethyl ester, hexadecanoic acid methyl ester, 9hexadecenoic acid, ethyl 9-hexadecenoate, (e)-9-octadecenoic acid ethyl ester, heptadecanoic acid, ethyl ester, octadecanoic acid, ethyl ester; 4,8,12,16-tetramethylheptadecan-4-olide, behenic alcohol, docosanoic acid, ethyl ester, hexacosylheptafluorobutyrate, ethyl tetracosanoate, 1-heptacosanol [20, 97, 101-04].

\section{Unsaturated fatty acids and its derivatives}

Unsaturated fatty acids and their derivatives are identified in $L$. sativum are $\gamma$-tocopherol, 8,11,14-eicosatrienoic acid methyl ester, linoleoyl chloride, trans-9,12-octadecadienoic acid propyl ester, ethyl $(9 z, 12 z)$-octadeca-9,12-dienoate, benzenepropanoic acid octadecyl ester [20, 97, 101-105].

Different monounsaturated fatty acids and their derivatives are identified include cis-9-hexadecenal; erucic acid, oleoyl chloride, (Z)-18octadec-9-enolide, (E)-3,7,11,15-tetramethylhexadec-2-en-1-ol, transphytol, dichloroacetic acid tridec-2-ynyl ester, (14r)-14-methylhexadec- 
8-yn-1-ol, (z)-octadec-9-enal;fumaric octadecyl ester [20, 101, 102, 104].

\section{Phytosterols and its derivatives}

Phytosterols are the phytoconstituent which have steroidal skeleton. They serve lots of advantages as they act as steroids present in human body. Important phytosterols such as stigmasterol, $\gamma$-Stigmasterol; $\beta$ sitosterol, campesterol, isofucosterol, squalene, along with [(3s)-17[(e)-5-ethyl-6-methylhept-3-en-2-yl]-10,13-dimethyl 2,3,4,7,8,9,11,12, 14,15,16, 17-dodecahydro-1h-cyclopenta[a]phenanthren-3-yl] acetate, stigmast-5-en-3-ol, oleate, stigmast-5-en-3-ol, 4-campestene-3-one, 4,22-stigmastadiene-3-one, gamma-sitostenone, $\quad(5 r, 8 s, 9 s, 10 r, 13 r$, 14s,17r)-4,4,10,13-tetramethyl-17-[(2r)-6-methylheptan-2-yl]-2,5,6,7, $8,9,11,12,14,15,16,17$-dodecahydro-1h-cyclopenta[a]phenanthren-3one,(5s,8s,9s,10r,13r,14s,17r)-17-[(2r,5r)-5-ethyl-6-methylheptan-2-yl]10,13-dimethyl2,4,5,7,8,9,11,12,14,15,16,17 -dodecahydro-1hcyclopenta[a]phenanthrene-3,6-dione have been identified in $L$. Sativum [101, 102, 104, 106].

\section{Amino acids}

Essential amino acids and non-essential amino acids both are required for human body development. Entire genomes of human based on amino acids but human body dose not generate these amino acids by themselves. In such situation amino acids are taken from the natural sources. L. sativum is reach in amino acid content, some of them are mentioned in Table 5 and their percentage description given in Fig. 6 [4, $20,22,97,100]$.

\section{Volatile compounds/aromatic compounds}

Seeds of L. Sativum contain plenty of volatile oil that is rich in neral, citral, linalool (monoterpenoid), carvone (terpenoid), linalyl acetate, geraniol (monoterpenoid), terpinyl formate, eugenol, geranyl acetate, methyl eugenol, (4R,4aR)-1,1,4,7-tetramethyl-1a,2,3,4,4a,5,6,7boctahydrocyclopropa[e] azulene (tricyclic sesquiterpene), caryophyllene (bicyclic sesquiterpene), 1,2-15,16-diepoxyhexadecane, 1,2-benzenedicarboxylic acid ${ }^{[101,104]}$.

\section{Organic compounds}

Important secondary metabolites recorded in the L. Sativum comprise kaempferol-7-O- $\alpha$-L-rhamnopyranoside; quercetin-7-O-L-rhamnoside; rutin; 3-methoxy-4-hydroxybenzoic acid; syringaldehyde; 2phenylacetamide; benzoic acid, 2-(dimethylamino) ethyl ester; benzyl nitrile; (isothiocyanatomethyl)-; 3',5'-dimethoxyacetophenone; 2(dimethylamino) ethyl 3-cyclopentylpropanoate; 4-0-[2(dimethylamino) ethyl] 1-O-nonyl (E)-but-2-enedioate; O-ethyl s-2dimethylamino ethyl ethyl phos; eucalyptol; benzyl isocyanate; 2,4ditert-butyl-6-(1-phenylethyl)phenol; neophytadiene; 1,5-pent-2-ene3-methyl-5-(2,6- dimethylhept; 3-cyclopenta-2,4-dien-1-yl-n,ndimethylpropan-1-amine; 3-cyclopentylpropionic acid 2dimethylaminoethyl ester; 1-cyclohexyldimethylsilyloxybutane; cyclododecanone; 2-(3-hydroxybutyl)-2-nit [101, 104, 106].

\section{Pharmacological activity}

\section{Anti carcinogenic activity}

Phenolics compound present in the seed coat of $L$. sativum has been shown to possess inhibitory action of trypsin with an IC50 value of 14.6 $\mu \mathrm{g} / \mathrm{mL}{ }^{[32]}$. L. sativum juice is reported to exhibit protective action against benzo(a)pyrene-induced DNA damage in human derived cells [33]. Furthermore, chemoprotective effect of $L$. sativum constituents, glucotropaeolin and benzylisothiocyanate is shown to be mediated through enhancement of detoxification of 2-amino-3-methyl-imidazo [4,5-f] quinoline by glucuronosyl transferase [34-36]. The methanolic extract is shown to be cytotoxic in MTT and neutral red assays in-vitro on colon and endometrium cancer cells and human peripheral lymphocyte cells in a concentration-dependent manner. A high content of phenolic and flavonoid compounds in the extract is shown to be responsible for significant antioxidant activity. Apoptotic activity and genotoxic effects of the plant extract were significantly found to be increasing with $200 \mu \mathrm{g} / \mathrm{ml}$ concentrations at 48 hours incubation [37]. Alkaloid extract of $L$. sativum containing six alkaloids and protoalkaloids, viz., benzyl isothiocyanate (1), 2-ethoxy-4H-3,1-benzoxazin-4one (2), (4R)-2-(2-aminophenyl)-4-phenyloxazoline (3), 5-acetyl-1,2dihydro-6-methyl-2-oxo-4-phenyl-3-pyridinecarbonitrile (4), benzo[b, 1,8]-naphthyridin-5(10H)-one,2,4,7-trimethyl (5) and 1,4diaminoanthraquinone (6) is reported to be cytotoxic to Jurkat E6-1 cells, with median lethal concentration ( $\mathrm{LC}_{50}$ ) of $75.25 \mu \mathrm{g} / \mathrm{mL}$. In further experiments with Jurkat cells at $L C_{50}$ and sub-LC $C_{50}$ doses the extract is shown to demonstrate DNA fragmentation, activate caspase- 3 and cause time-dependant phosphatidylserine translocation (apoptosis) from inner to outer cell membranes ${ }^{[38]}$. However, the alkaloid extract is also shown to be possessing nontoxic and proliferative (1.6-fold) effects in healthy PBMCs. The aqueous extract of seed is shown to inhibit growth of breast cancer cells MCF-7 cells, time and dosedependent manner [39].

\section{Anti-diarrheal and anti-spasmodic activities}

The methanolic extract of $L$. sativum seeds is reported to have a substantial reduction in the severity and frequency of diarrhoea produced by castor oil due to the ability of the extract to increase reabsorption of $\mathrm{NaCl}$ and water by decreasing the intestinal motility. Further, this activity of the extract is attributed to the presence of flavonoids, alkaloids and saponins that are known for inhibiting autacoid and prostaglandin, in that way inhibiting the motility and secretion ${ }^{[62-67]}$.

In various animal experimental studies the crude extract of $L$. sativum is shown to exert antispasmodic effect through a combination of multiple pathways including activation of $\mathrm{K}+$ channels, and inhibition of muscarinic receptors, Ca++ channels and PDE enzyme [62, 64, 65, 68].

\section{Anti-hypertensive activity}

The aqueous extract of $L$. sativum in various experiments is shown to cause a significant decrease in blood pressure while no changes in heart rate $[41,60,70,97,99,107-109]$. 


\section{Anti-inflammatory activity}

Several studies on anti-inflammatory potential of seed oil of $L$. sativum report its potential to alleviate inflammatory conditions by modulating inflammatory mediators such as NO and leukotriene B4 and the effect has been attributed presence of $\alpha$-linolenic acid, 7,10-hexadecadienoic acid, 11-octadecenoic acid, 7,10,13- hexadecatrienoic acid, and behenic acid in the seed oil at $300 \mu \mathrm{g} / \mathrm{mL}\left[{ }^{[1,}, 6\right]$. The anti-inflammatory activity of methanolic extract of seed was studied in rats at three different doses $50 \mathrm{mg} / \mathrm{Kg}, 100 \mathrm{mg} / \mathrm{Kg}$, and $200 \mathrm{mg} / \mathrm{Kg}$ and the highest activity is shown to be at $50 \mathrm{mg} / \mathrm{kg}$ dose ${ }^{[43]}$. L. sativum crude extract containing a high concentration of flavonoids quercetin, kaempferol, luteolin, apigenin, naringin and naringenin has been found to mitigate inflammatory conditions in experimental animals [40]. In another study crude extract of $L$. sativum, polyphenols and organosulfur compounds are shown to be responsible for the antioxidant and anti-inflammatory activities [42]. The crude extract of $L$. sativum is shown to exert strong anti-inflammatory activity in carrageenan-induced paw oedema and reduce the yeast-induced hyperpyrexia by inhibiting the proliferation of fibroblasts and also modulation of connective tissue [30, 44, 45, 110].

\section{Anti-microbial activity}

The ethanol extract of seeds of L. sativum at $200 \mathrm{mg} / \mathrm{ml}$ is reported to inhibit growth of Streptococcus equine and Corynebacterium pseudotuberculosis [24]. In multiple experiments seed extracts (ethanol, methanol and chloroform) are assessed against different strains of bacteria like Klebsiella pneumoniae, Staphylococcus aureus, MethicillinResistance Staphylococcus aureus, Streptococcus pneumonia and Escherichia coli strains and the major compounds fatty acid esters and alkaloids are shown to be responsible for anti-microbial activity [25-31, 104, 111]. L. sativum seed oil is reported to possess anti-microbial effect against Pseudomonas aeruginosa, Salmonella enterica, K. pneumoniae, S. aureus, Bacillus subtilis, E. coli and Candida albicans ${ }^{[6]}$.

\section{Analgesic activity}

The methanolic extract of seed $L$. sativum rich in carbohydrates, proteins, fatty acids and vitamins ( 6 -carotene, riboflavin, niacin and ascorbic acid) along with volatile oils, fixed oils, flavanoids, isothiocynate glycoside is reported to possess analgesic activity in mice in tail flick and hot plate methods ${ }^{[43,45]}$. In one of the study on the neurobehavioral effects, the total alkaloid fraction from seeds of $L$. sativum is reported to considerably potentiate the thiopental induced hypnosis, decrease locomotor activity and motor coordination, and increase preference to plus maze open arm [112]. Flavonoidal constituents from the methanolic extract of $L$. sativum seed has been shown to give analgesic activity in rat model [113]. The seed of $L$. sativum is found to exert analgesic activity of in the acetic acid-induced writhing syndrome and formaldehyde-induced paw licking response by significantly increasing latency of onset and producing significant inhibition of neurogenic and inflammatory pain [114].

\section{Anti-osteoporotic effect}

Treatment with $L$. sativum is shown to improve the serum Ca, albumin, $P$, bone architecture bone-specific alkaline phosphatase (b-ALP), and decreased tartrate-resistant acid phosphatase (TRAP) in glucocorticoids-induced osteoporosis in experimental animals [114, 115].

\section{Anti-oxidant activity}

Lepidium seed oil consists of fatty acid (oleic acid and linoleic acid), $y$ tocopherol, $\delta$-tocopherol and flavonoid is reported to cause significant reduction in free oxidative species in blood [11, 47-50]. 7,10hexadecadienoic acid, 11-octadecenoic acid, 7,10,13- hexadecatrienoic acid, and behenic acid phytoconstituents found in L. sativum are shown to possess free radical scavenging activity (DPPH) ${ }^{[6,46]}$. Of the ethanolic extracts of different parts of $L$. sativum studied for antioxidant activity (DPPH assay) shoot extract is shown to be supreme in scavenging activity and stem as least active [51] In one of the study L. sativum antioxidant activity is reported against melanin production enhancement on exposure to UV-c radiation [116]. The activity of glutathione s-transferase enzyme, reduced glutathione activity and reducing power was found to be more in ethanolic extract of seed than other plant parts [51, 117].

\section{Anti-pyretic activity}

The methanolic extract of $L$. sativum in dose of $100 \mathrm{mg} / \mathrm{Kg}$ is reported to produce significant reduction in the yeast-induced hyperpyrexia (antipyretic effect) ${ }^{[45]}$.

\section{Bronchodilatory effects}

L. sativum is extensively used in traditional medicine to treat respiratory tract disorders, such as asthma, bronchitis and cough. The crude extract of $L$. sativum at higher concentration is shown to inhibit carbachol and $\mathrm{K}+$ induced contractions in a pattern which is similar to that of dicyclomine, suggesting that bronchodilatory effect of these crude extract is mediated through a combination of anticholinergic, calcium ion channel antagonist and phosphodiesterase inhibitory pathways, providing complete mechanistic background for its medicinal use in the overactive airways disorders [8, 9, 62, 70, 118-126].

\section{Cardioprotective effect}

The ethanolic extract of L. sativum (i.p.) is recorded to cause significant rise in blood pressure and increase the rate and force of auricular and ventricular movements of open chest cat heart preparation. The cardio-stimulant action is also reported to be observed on isolated rabbit auricles. It is noted in the study that the extract, when given intraperitoneal route to mice at up to $1000 \mathrm{mg} / \mathrm{kg}$, did not produce behavioural or toxic effects [127].

\section{Coagulant activity}

The ethanolic extract of $L$. sativum is shown to significantly increase in fibrinogen level and an insignificant decrease in prothrombin time, confirming its coagulating property ${ }^{[45]}$.

\section{Diuretic activity}

The aqueous extract of L. sativum produces has been shown to increase glomerular filtration rate causing significant increase of urinary excretion, along with sodium, potassium and chlorides ions in normotensive rats ${ }^{[60]}$. The aqueous saponin rich fraction extract of $L$. sativum on oral administration is reported to show dose-dependent increase in urinary excretion along with sodium ion excretion [61]. 


\section{Fracture healing activity}

L. sativum is reported to show fracture healing activity in fracture in the midshaft of the left femur induced in adult white rabbits [94, 107, 128].

\section{Growth performance and gonadotropins secretion}

The gonadotropins effect of L. sativum seed supplement because of presence of phytosterols is reported to be mediated through the activation of estrogen receptors thereby producing agonistic effects that resulted in significant increase in LH and FSH secretion dosedependently in rabbits ${ }^{[129]}$.

\section{Hepatoprotective effect}

L. sativum has been widely used to treat numeral aliments in our folk medicine. Many investigations are done to ensure hepatoprotective this activity of $L$. sativum. The extract of $L$. sativum is noted to reduce oxidative stress and thereby reduce cytotoxicity induced by hydrogen peroxide in the human liver cell (HepG2) ${ }^{[14]}$. In an experimental study, the ethanolic extract of $L$. sativum is shown to significantly decrease oxidative stress markers, protein level and albumin level along with down-regulating mRNA expression of iNOS and HO-1 and also noted to cause concomitant increase in MPO activity and NFkB DNA-binding effect $[15,16]$. The seed oil of $L$. sativum also is recorded to exhibit hepatoprotective activity by helping in reducing bad cholesterol and hence improving liver enzyme activity ${ }^{[17]}$. In an experiment, L. sativum is rated as functional food that possesses number of activities and hepatoprotective activity is one of them ${ }^{[18]}$.

\section{Hypoglycemic activity}

In our folk medicine $L$. sativum is used to treat diabetes as well. There are many evidences which give base to this claim. Many scientific activities have been done to establish proper mechanism of hypoglycemic activity of $L$. sativum as raw and its crude extract.

Oxidative stress is a major cause of diabetes and its associated complication. In streptozotocin along with high-fat diet diabetes mellitus experimental mouse model among raw L. sativum and crude extract, the former is reported to give better effect as evidenced by significant reduction into the blood glucose level and improved blood lipid metabolism in diabetic mice by improving activity of antioxidant defence enzymes with improved the body's antioxidant emergency response [16, 130, 47, 53]. The flavonoid rich extract of $L$. sativum is shown to improve insulin sensitivity, dyslipidaemia, inflammation, and pancreas $B$ cell integrity ${ }^{[40]}$. A research study shows that trace element present in plant gives antidiabetic activity ${ }^{[131]}$. The methanolic extract of the L. sativum is shown to exhibit potent antioxidant and hypoglycemic activity in alloxan-induced diabetic rate model through changing the pathology of the pancreas [54]. In some of the experimental studies $L$. sativum is given as a dietary supplement and daily consumption of seeds of $L$. sativum is reported to significantly improve body functioning. Also, phenolics present in the seed coat of the L. sativum are noted to inhibit carbohydrate hydrolysing enzymes such as $\alpha$-amylase and $\alpha$-glucosidase and lower postprandial glucose level [32]. Furthermore, imidazole alkaloids, lepidine and semilepidine of seeds of $L$. sativum are reported to produce antidiabetic action by the potentiating of pancreatic secretion of insulin from the remaining islet $\beta$-cells ${ }^{[55]}$. The aqueous $L$. sativum extract is shown to inhibit renal glucose reabsorption which in turn reduce blood sugar [132, 133]. All of this experiment conclude that $L$. sativum have significant role in hypoglycemic activity [107, 111, 118, 134-138].

\section{Hypolipidemic activity}

There are several experiments which provide strong evidence for the hypolipidemic activity of $L$. sativum. Several experimental reports show that after consumption of L. sativum in raw form or extract, there a significant reduction in total cholesterol (TC), triglyceride (TG), lowdensity lipoprotein (LDL) while the major increase in high-density lipoprotein (HDL) level indicating improved lipid metabolism because of flavonoids [16-18, 30, 40, 48, 52-58, 139-141].

\section{Laxative activity}

The seeds of $L$. sativum have been shown to possess a strong laxative effect in mice and thus supports a rationale for its traditional use in indigestion and constipation. Various experiments performed on the intestine and jejunum tissue of rat, mice, and rabbit revealed that tissue selectivity differed based on the type of animal tissue. The methanolic seed extract of $L$. sativum is reported to be antidiarrheal as well as laxative ${ }^{[67]}$.

\section{Menstrual cycle regulation}

One of the experiments aimed to determine the effect of the $L$. sativum seed consumption on the endocrinology of ovulation and the development of visceral organs in the rat model. showed that $L$. sativum supplementation tended to cause an earlier, attenuated preovulatory surge-like GnRH secretion. Also temporally, luteinizing hormone (LH) secretion from the pituitary gland in all treatment groups decreased over time. Overall, follicle-stimulating hormone (FSH) decreased from time 0 to about $180 \mathrm{~min}$ before stabilizing. L. sativum extract administration is reported to significantly increase average FSH secretion in ovariectomized, estrogen-primed rats but did not affect in the ovariectomized, estrogen-primed, and progesterone-treated rats [142].

\section{Nephroprotective and curative activities}

L. sativum is reported to give compelling nephroprotective and curative activities by scavenging of free oxidative radicals in cisplatin induced nephrotoxicity experimental animal model. The methanolic seed extract balanced border enzymes like $\mathrm{Na}+\mathrm{K}+$ ATPase, $\mathrm{Ca}++$ ATPase and Mg++ ATPase [32, 46, 71, 123, 143-145].

\section{Male fertility improvement}

In one of the experiment, Oral supplementation of tocopherol extracted from seeds of $L$. sativum is reported to improve histoarchitecture of rabbit testis and could be used to improve the fertility of rabbits ${ }^{[105]}$. 


\section{CONCLUSION}

L. sativum has been used for many purposes. The scientific research on L. sativum suggests a huge biological potential of this plant. L. sativum has been used as nutraceuticals, and pharmaceutical excipient. Besides being used as nutraceutical and pharmaceutical excipients $L$. sativum has been extensively used for functional food and as a traditional medicine. Besides being used as traditional medicines, several compounds and extracts of $L$. sativum showed pharmacological activities. It is believed that detailed information as presented in this review on pharmacognostical, phytochemical and various pharmacological activities and the uses of different extracts might provide detailed evidence for the use of this plant in different medicinal systems. The phytochemical variations and efficacy of the medicinal values of the $L$. sativum is dependent on geographical location. L. sativum is effective in asthma, cough, gastrointestinal track disorders, cardiac disease, diabetes, hepatic function, infections and many more. Therefore, with appropriate management, L. sativum could be promoted to be used for the benefits of local people and industry, especially pharmaceutical industry, and it may enhance food security, health security, environmental security and economic security.

\section{Conflict of Interest}

None declared.

\section{Financial support and sponsorship}

Nil.

\section{REFERENCES}

1. Flora of North America, http://www.efloras.org/florataxon.aspx? flora_id=1\&taxon_id=200009589, reviwed on 14-4-2020. Nature 1972; 239:414-414.

2. Flora of Pakistan, http://www.efloras.org/florataxon.aspx? flora_id=5\&taxon_id=200009589, reviewed on 14-4-2020.

3. Government of India, Ministry of Health and Family Welfare new delhi. The Ayurvedic Pharmacopoeia of India. 1990; 1:28.

4. Kirtikar KR BB. Indian Medicinal Plants. vol-1. Dehradun, 1933.

5. Angel R, Chadha YR. The Wealth of India. Raw Materials. Kew Bull. 1978; 32:802.

6. Alqahtani FY, Aleanizy FS, Mahmoud AZ, et al. Chemical composition and antimicrobial, antioxidant, and anti-inflammatory activities of Lepidium sativum seed oil. Saudi J. Biol. Sci. 2019; 26(5):1089-1092.

7. Paranjape AN, Mehta AA. A study on clinical efficacy of Lepidium sativum seeds in treatment of bronchial asthma. Iran. J. Pharmacol. Ther.

8. Dogra K.S., Chauhan S., Jalal JS. Assessment of Indian medicinal plants for the treatment of asthma. J. Med. Plants Res. 2015; 9(32):851-862.

9. Sharma M, Arora A., Gupta S. Ethno-medicinal studies of plants used for the treatment of asthma by indigenous communities of chamba (himachal pradesh). Int. J. Pharm. Biol. Sci. 2018; 8(1):314-317.

10. Chopra R, Nayar S, Chopra I. Glossary of Indian Medicinal Plants. 1956. Epub ahead of print 1956. DOI: 10.1016/j.gyobfe.2006.11.001.

11. Zia-Ul-Haq M, Ahmad S, Calani L, et al. Compositional study and antioxidant potential of Ipomoea hederacea Jacq. and Lepidium sativum L. seeds. Molecules 2012; 17(9):10306-10321.

12. Sakran M., Selim Y., Zidan N. A new isoflavonoid from seeds of Lepidium sativum L. and its protective effect on hepatotoxicity induced by paracetamol in male rats. Molecules. Epub ahead of print 2014. DOI: 10.3390/molecules191015440.
13. Abuelgasim A., S. N. HA. Hepatoprotective Effect of Lepidium sativum Against Carbon Tetrachloride Induced Damage in Rats. Res. J. Anim. Vet. Sci.

14. Al-Sheddi ES, Farshori NN, Al-Oqail MM, et al. Protective effect of Lepidium sativum seed extract against hydrogen peroxide-induced cytotoxicity and oxidative stress in human liver cells (HepG2). Pharm. Biol. 2016; 54(2):314-321.

15. Khalid RMMKA-JFIA-MAMAAA, Ahmad A. Hepatoprotective activity of Lepidium sativum seeds against D-galactosamine/lipopolysaccharide induced hepatotoxicity in animal model. BMC Complement. Altern. Med. 2016; 16(1):501.

16. Chen, Xi., Yuan H., Shi F, Zhu Y. Effect of Garden Cress in Reducing Blood Glucose, Improving Blood Lipids and Reducing Oxidative Stress in a Mouse Model of Diabetes Induced by a High Fat Diet and Streptozotocin. J. Sci. Food Agric. 2019; 100:2074-2081.

17. Mohamed DA, Essa HA, Mohamed RS. Purslane and garden cress seeds as source of unconventional edible oils for prevention of hyperlipidemia. Pakistan J. Biol. Sci. 2019; 22(11):537-544.

18. Mohamed DA, Abdelgayed SS, Essa HA, et al. Preparation and evaluation of functional foods for prevention of non-alcoholic fatty liver disease. Pakistan J. Biol. Sci. 2018; 21(9):454-462.

19. Halls LK, Uphof JCT. Dictionary of Economic Plants. Journal of Range Management. Epub ahead of print 1961. DOI: 10.2307/3894835.

20. Ghedeir MA., Mohammed A.Y. Nutritive value of elrashad (Lepidium sativum I.) seeds grown in saudi arabia. J. Exp. Biol. Agric. Sci. 2017; 5:155159.

21. Koli P, Kumar J, Singh BB, et al. Mineral Profiling and Phytochemical Assessment of Lepidium sativum Seeds from Tropical Western India. Int. J. Curr. Microbiol. Appl. Sci. 2018; 7(8):3720-3728.

22. Gokavi SS, Malleshi NG, Guo M. Chemical composition of garden cress (Lepidium sativum) seeds and its fractions and use of bran as a functional ingredient. Plant Foods Hum. Nutr. 2004; 59:105-111.

23. Jangra SS, Madan VK. Phytochemical and Nutritional Composition of Different Parts of Garden Cress (Lepidium sativum L.). Int. J. Curr. Microbiol. Appl. Sci. 2018; 7(11):1136-1145.

24. Endrise J., Assefa Z., Dawo F., Abera D. An in vitro antibacterial activity test of Phytolaca dodecandra, Adhatoda schimperiana and lepidium sativum against two major skin bacterial pathogens of equine. Glob. Vet. 2019; 21(4):232-239.

25. Saddiq AA, Mohamed AM. Susceptibility Assessment of MethicillinResistant Staphylococcus aureus Strains to Lepidium sativum Extract. Dose-Response; 17(2). Epub ahead of print 2019. DOI: $10.1177 / 1559325819850425$.

26. Abdel-Aty AM, Bassuiny RI, Barakat AZ, et al. Upgrading the phenolic content, antioxidant and antimicrobial activities of garden cress seeds using solid-state fermentation by Trichoderma reesei. J. Appl. Microbiol. 2019; 127(5):1454-1467.

27. Rafińska K, Pomastowski P, Rudnicka J, et al. Effect of solvent and extraction technique on composition and biological activity of Lepidium sativum extracts. Food Chem. 2019; 289:16-25.

28. Ait-Yahia O, Perreau F, Bouzroura SA, et al. Chemical composition and biological activities of $n$-butanol extract of Lepidium sativum $L$ (Brassicaceae) seed. Trop. J. Pharm. Res. 2018; 17(5):891-896.

29. Abdel Karim M., Sufian, A., Kamal, M. S., Inas O. GC-MS analysis and antimicrobial activity of fixed oil from Saudi Lepidiumsativum (Crusifereae) seeds. Int. J. Adv. Res. 2017; 5(3):1662-1670.

30. Tounsi N, Djerdjouri B, Yahia OA, et al. Pro-oxidant versus anti-oxidant effects of seeds aglycone extracts of Lepidium sativum and Eruca vesicaria Linn., in vitro, and on neutrophil nitro-oxidative functions. J. Food Sci. Technol. 2019; 56(12):5492-5499.

31. Aragaw Z, Nega B. Synergistic antibacterial effect of Lepidium sativum and Coriandrum sativum against standard and drug resistant clinically isolated pathogenic bacteria. African J. Biotechnol. 2017; 16(33):1743-1757. 
32. Doke S., Sreerama, Y. N., Guha M. Inhibitory effects of garden cress (Lepidium sativum L.) seed coat phenolics on $\alpha$-amylase, $\alpha$-glucosidase and trypsin. Int. J. Pharm. Res. Bio-Science 2016; 5(1):68-76.

33. Siegfried K. Effects of garden and water cress juices and their constituents, benzyl and phenethyl isothiocyanates, towards benzo(a)pyrene-induced DNA damage: a model study with the single cell gel electrophoresis/Hep G2 assay. Chem. Biol. Interact. 2003; 142(3):285-296.

34. Siegfried K. Chemoprotective effects of garden cress (Lepidium sativum) and its constituents towards 2-amino-3- methyl-imidazo[4,5-f]quinoline (IQ)-induced genotoxic effects and colonic preneoplastic lesions. Carcinogenesis 2002; 23(7):1155-1161.

35. Abd El-Kaream SA. Biochemical and biophysical study of chemopreventive and chemotherapeutic anti-tumor potential of some Egyptian plant extracts. Biochem. Biophys. Reports. Epub ahead of print 2019. DOI: 10.1016/j.bbrep.2019.100637.

36. Soundararajan P, Kim JS. Anti-carcinogenic glucosinolates in cruciferous vegetables and their antagonistic effects on prevention of cancers. Molecules. Epub ahead of print 2018. DOI: 10.3390/molecules23112983.

37. Selek S, Koyuncu I, Caglar HG, et al. The evaluation of antioxidant and anticancer effects of Lepidium Sativum Subsp Spinescens L. methanol extract on cancer cells. Cell. Mol. Biol. 2018; 64(3):72-80.

38. Basaiyye SS, Kashyap S, Krishnamurthi $\mathrm{K}$, et al. Induction of apoptosis in leukemic cells by the alkaloid extract of garden cress (Lepidium sativum L.). J. Integr. Med. 2019; 17(3):221-228.

39. Mahassn SH, Al-Reemi RM. Cytotoxic effect of an aqueous extract of Lepidium sativum L. seeds on human breast cancer cells. Indian J. Tradit. Knowl. 2013; 12(4):605-614.

40. L'hadj I, Azzi R, Lahfa F, et al. The nutraceutical potential of Lepidium sativum $L$. seed flavonoid-rich extract in managing metabolic syndrome components. J. Food Biochem.; 43(3). Epub ahead of print 2019. DOI: 10.1111/jfbc.12725.

41. Diwakar BT, Ramaswamy Lokesh B, Naidu KA. Modulatory effect of $\alpha$ linolenic acid-rich garden cress (Lepidium sativum L.) seed oil on inflammatory mediators in adult albino rats. Br. J. Nutr. 2011; 106(4):530539.

42. Türkoğlu M, Kılıç S, Pekmezci E, et al. Evaluating antiinflammatory and antiandrogenic effects of garden cress (Lepidium sativum L.) in $\mathrm{HaCaT}$ cells. Rec. Nat. Prod. 2018; 12(6):595-601.

43. Shadmani A., Rizwani GH., Ahmed M. Potential analgesic effect of Cissus quadrangularis L. and Lepedium sativum L. along with their combination extracts. Int. J. Pharm. Chem. Biol. Sci. 2017; 7(2):122-127.

44. Raval N, Ravishankar B, Ashok B. Anti-inflammatory effect of Chandrashura (Lepidium sativum Linn.) an experimental study. AYU (An Int. Q. J. Res. Ayurveda) 2013; 34(3):302-304.

45. Al-Yahya MA, Mossa JS, Ageel AM, et al. Pharmacological and safety evaluation studies on Lepidium sativum L., Seeds. Phytomedicine 1994; 1(2):155-159.

46. Ahamad R, Mujeeb M, Anwar F, et al. Phytochemical analysis and evaluation of anti-oxidant activity of methanolic extract of Lepidium sativum L. seeds. Der Pharm. Lett. 2015; 7(7):427-434.

47. Desai S. S., Walvekar M. V., Khairmode SP. Free radical scavenging activity of lepidium sativum seed extract in $\mathrm{hfd} / \mathrm{stz}$ induced diabetes. Int. J. Pharma Bio Sci. 2018; 9(2):127-132.

48. Stüven J, Pflugmacher S. Antioxidative stress response of Lepidium sativum due to exposure to cyanobacterial secondary metabolites. Toxicon 2007; 50(1):85-93.

49. Lotfy $M$, Aref $H$, Hussein AA. The antioxidant properties of garden cress (Lipidium sativium) and wild mustard (Sinapsis arvensis) oils. J. Am. Oil Chem. Soc. 1957; 34:96-100.

50. Umesha SS, Naidu KA. Antioxidants and antioxidant enzymes status of rats fed on n-3 PUFA rich Garden cress (Lepidium Sativum L) seed oil and its blended oils. J. Food Sci. Technol. 2015; 52(4):1993-2002.

51. Malar J, Chairman K, Singh ARJ, et al. Antioxidative activity of different parts of the plant Lepidium sativum Linn. Biotechnol. Reports 2014; 3:9598.
52. Umesha SS, Naidu KA. Vegetable oil blends with $\alpha$-linolenic acid rich Garden cress oil modulate lipid metabolism in experimental rats. Food Chem. 2012; 135(4):2845-2851.

53. Qusti S, El Rabey HA, Balashram SA. The Hypoglycemic and Antioxidant Activity of Cress Seed and Cinnamon on Streptozotocin Induced Diabetes in Male Rats. Evidence-based Complement. Altern. Med. Epub ahead of print 2016. DOI: 10.1155/2016/5614564.

54. Attia ES, Amer AH, Hasanein MA. The hypoglycemic and antioxidant activities of garden cress (Lepidium sativum L.) seed on alloxan-induced diabetic male rats. Nat. Prod. Res. 2019; 33(6):901-905.

55. Shukla A, Bigoniya P, Srivastava B. Hypoglycemic activity of lepidium sativum linn seed total alkaloid on alloxan induced diabetic rats. Res. J. Med. Plant 2012; 6(8):587-596.

56. Ghiliyal P., Bhatt A. Medicinal plants for treatment of liver disorders. World J. Pharm. Pharm. Sci. 2017; 6(8):326-337.

57. El-Aziz MA, Haggag HF, Kaluoubi MM, et al. Evaluation of hypolipedimic activity of ethanol precipitated cress seed and flaxseed mucilage in wister albino rats. Res. J. Pharm. Biol. Chem. Sci. 2016; 7(4):606-613.

58. Reddy KVK, Naidu KA. Maternal supplementation of $\alpha$-linolenic acid in normal and protein-restricted diets modulate lipid metabolism, adipose tissue growth and leptin levels in the suckling offspring. Eur. J. Nutr. 2015; 54(5):761-770.

59. Patel U, Kulkarni M, Undale V, et al. Evaluation of diuretic activity of aqueous and methanol extracts of Lepidium sativum Garden Cress (Cruciferae) in rats. Trop. J. Pharm. Res. Epub ahead of print 2009. DOI: 10.4314/tjpr.v8i3.44536

60. Maghrani M, Zeggwagh NA, Michel JB, et al. Antihypertensive effect of Lepidium sativum L. in spontaneously hypertensive rats. J. Ethnopharmacol. 2005; 100(1-2):193-197.

61. Abdel Mahmoud El Tayb H.,; Abdel KM., Ghada M., Mudawi MME. Evaluation of diuretic activity of aqueous methanol and saponin rich fraction extracts of Lepidium sativum seeds (Garden Cress) in rats. PHARMANEST 2016; 7(2):3063-3066.

62. Jain T, Grover K. A Comprehensive Review on the Nutritional and Nutraceutical Aspects of Garden Cress (Lepidium sativum Linn.). Proc. Natl. Acad. Sci. India Sect. B - Biol. Sci. 2018; 88(3):829-836.

63. Behrouzian F, Razavi SMA, Phillips GO. Cress seed (Lepidium sativum) mucilage, an overview. Bioact. Carbohydrates Diet. Fibre 2014; 3(1):17-28.

64. Rehman NU, Mehmood MH, Alkharfy KM, et al. Studies on antidiarrheal and antispasmodic activities of lepidium sativum crude extract in rats. Phyther. Res. 2012; 26(1):136-141.

65. Gilani $\mathrm{AH}$, Rehman $\mathrm{NU}$, Mehmood $\mathrm{MH}$, et al. Species differences in the antidiarrheal and antispasmodic activities of lepidium sativum and insight into underlying mechanisms. Phyther. Res. 2013; 27(7):1086-1094.

66. M. Ibrahim M, M. Mounier M, Bekheet SA. Glucosinolates Constituents and Cytotoxic Activities of Lepidium sativum L. Callus Cultures. J. Environ. Sci. Technol. 2019; 12(3):138-148.

67. Region $\mathrm{Q}$, Arabia S, Al-harbi KB, et al. The antidiarrheal activity of the methanol extract of some plants native to Al-Qassim Region, Saudi Arabia. J. food Agric. Environ. 2016; 14(2):238-243.

68. Doke S. GM. Garden cress (Lepidium sativum L.) Seed - An Important Medicinal Source : A Review. J. Nat. Prod. Plant Resour. 2014; 4(1):69-80.

69. Strain J, Caballero B, Sadler M. Encyclopedia of human nutrition. 2010. Epub ahead of print 2010. DOI: 10.1016/C2009-1-03773-3.

70. Agarwal N, Sharma S. Exploration and utilization of garden cress seeds (Lepidium sativum) through product development endeavour. In: Gaur, R. K.; Sharma, K. P.; Chundawat RS (ed) Microbial, Plant and Animal Research. 2013, pp. 69-74.

71. Adam SEI. Effects of various levels of dietary lepidium sativum I. seeds in rats. Am. J. Chin. Med. 1999; 27(3-4):397-405.

72. M. Angel KPVD. Effect of Garden Cress Seeds Incorporated Health Mix among Selected Anaemic Adolescent Girls (12-15 Years) in Dindigul District, Tamil Nadu, India. Int. J. Sci. Res.

73. Ramalingum N, Mahomoodally MF. The therapeutic potential of medicinal foods. Adv. Pharmacol. Sci. 2014; 2014(2):354264. 
74. Nadkarni KM (Krishnarao M. Dr. K. M. Nadkarni's Indian materia medica, with Ayurvedic, Unani-Tibbi, Siddha, Allopathic, Homeopathic, Naturopathic \& home remedies, appendices \& indexes / originally edited by K. M. Nadkarni ; rev. \& enlarged by A.K. Nadkarni. 3rd ed. bombay: Popular Prakashan, 1954.

75. Bigoniya $P$, Singh CS, Shukla A. Pharmacognostical and physicochemica standardization of ethnopharmacologically important seeds of Lepidium sativum Linn. and Wrightia tinctoria R. Br. Indian J. Nat. Prod. Resour. 2011; 2:464-471.

76. Ghosh-Jerath $\mathrm{S}$, Singh $\mathrm{A}$, Kamboj $\mathrm{P}$, et al. Traditional Knowledge and Nutritive Value of Indigenous Foods in the Oraon Tribal Community of Jharkhand: An Exploratory Cross-sectional Study. Ecol. Food Nutr. 2015; 54(5):1-27.

77. Hanan MAA-S, Nahla SZ, Abdelaleem MA. Utilization of Garden Cress Seeds (Lepidium sativum L.) as Natural Source of Protein and Dietary Fiber in Noodles. Int. J. Pharm. Res. Allied Sci.

78. Zanvar VS, Devi R. Biofortification of biscuits with garden cress seeds for prevention of anaemia. Asian J. Home Sci. 2007; 2:1-15.

79. Mohite SY, Gharal DB, Ranveer RC, et al. Development of health drink enriched with processed garden-cress (Lepidium sativum L.) seeds. Am. J. Food Technol. 2012; 7:571-576.

80. Kotagi K, Chimmad B, Naik R KM. Nutrient enrichment of little millet (Panicum miliare) flakes with garden cress seeds. Int. J. Food Sci. Nutr. 2013; 2:36-39.

81. Guddad S BP. Formulation and evaluation of cereal based health mix for pre school children. Asian J. Home Sci. 2014; 9:44-49.

82. Sharma S, Agarwal N CR. Bengal gram dhal flour ladoo improvisation incorporating red kidney beans (Phaseolus vulgaris L.) and garden cress seeds (Lepidium sativum L.). J. Sci. Technol. Environ. Informatics 2013; 2(1):71-79.

83. Angel M, Devi KPV. Therapeutic impact of garden cress seeds incorporated ladoo among the selected anaemic adolescent girls ( $12-15$ years ). J. Drug Discov. Ther. 2015; 3:18-22.

84. Elizabeth KGG PR. Organoleptic attributes of garden cress seed incorporated snacks suitable for adolescents. Int. J. Food Nutr. Sci. 2014; 3(6):126-129.

85. Lohekar Amruta S. AAB. Development of Value Added Instant 'Dhokla' Mix. Int. J. Food Nutr. Sci. 2014; 3:78-83.

86. Nathiya. MN, Dr. Nora VD. Formulation of Cereal Based Nutricookies Prepared Incorporating Garden Cress Seeds (Lepidium Sativum) - A Protein And Iron Rich Snack. Int. J. Sci. Res. 2012; 3:225-226.

87. Datta PK, Diwakar BT, Viswanatha S, et al. Safety evaluation studies on Garden cress (Lepidium sativum L.) seeds in Wistar rats. Int. J. Appl. Res. Nat. Prod.

88. Agarwal N, Sharma S. Appraisal of garden cress (lepidium sativum I.) and product development as an all pervasive and nutrition worthy food stuff. Ann. Food Sci. Technol. 2013; 14(1):77-84.

89. Aykroyd W, Gopalan C, Balasubramanian S. The nutritive value of Indian foods and the planning of satisfactory diets. New Delhi, 1963.

90. Agarwal N SS. Garden cress: an untapped environmentally sustainable foodstuff and health enhancer. J. Hum. Dev. 2011; 3(1):63-70.

91. Caballero B. Encyclopedia of Human Nutrition. 2012. Epub ahead of print 2012. DOI: 10.1046/j.1523-5408.2000.00085-2.x.

92. Coulston AM. Foods \& Nutrition Encyclopedia. 1994. Epub ahead of print 1994. DOI: 10.1093/ajcn/60.4.646.

93. Patel MM, Chauhan GM, Patel LD. Mucilages of Lepidium sativum, Linn. (Asario) and Oocimum canum, Sims (Bavchi) as emulgents. Indian J. Hosp. Pharm. 1987; 200-202.

94. Bansal D, Bhasin P, Yadav OP, et al. Assessment of genetic diversity in Lepidium sativum (Chandrasur) a medicinal herb used in folklore remedies in India using RAPD. J. Genet. Eng. Biotechnol. 2012; 10(1):39-45.

95. Saddoud A, Ellouze M, Dhouib A, et al. A comparative study on the anaerobic membrane bioreactor performance during the treatment of domestic wastewaters of various origins. Environ. Technol. 2006; 27(9):991-999.
96. Latif M, Licek E. Toxicity assessment of wastewaters, river waters, and sediments in Austria using cost-effective microbiotests. Environ. Toxicol. 2004; 19(4):302-309.

97. Prajapati MR., Dave PH. Therapeutic and nutritional importance of garden cress seed. J. Pharmacogn. Phytochem. 2018; 7(5):140-143.

98. Gopalan C, Rama Shastri B, Balasubramanian S. Nutritive value of Indian Foods. hyderabaad, 1987. Epub ahead of print 1987. DOI: $10.2307 / 302397$.

99. Sat IG, Yildirim E, Turan M, et al. Antioxidant and nutritional characteristics of garden cress (Lepidium sativum). Acta Sci. Pol. Hortorum Cultus 2013; 12(4):173-179.

100. Olaofe O, Adeyemi FO, Adediran GO. Amino Acid and Minera Compositions and Functional Properties of Some Oilseeds. J. Agric. Food Chem. 1994; 42:878-881.

101. Solomon G, Aman D, Bachheti RK. Fatty acids, metal composition, nutritional value and physicochemical parameters of Lepidium sativium seed oil collected from Ethiopia. Int. Food Res. J. 2016; 23(2):827-831.

102. Bhakare HA, Kulkarni AS, Khotpal RR. Lipid-Composition of Some Seeds of Central India. J. Food Sci. Technol. 1993; 30:54-55.

103. U.S. S, N.K. A. Garden cress (Lepidium sativum L.) seed oil: Alternative source for ALA. FASEB J.

104. Malar, Jency; Vanmathi, J. Shifa; Chairman K. Phytochemical analysis of lepidium sativum using UV-VIS and GC-MS. Int. J. Adv. Res. 2018; 6(9):813825.

105. Nada Saad Naji FMS. The Effects of Tocopherol Extraction from Lepidium Sativum Seed on the Histology of Testis, Epididymis, and Seminal Vesicles of Adult Male Rabbits. J. Biol. Agric. Healthc.; 3(6).

106. A. Kaiyrkulova, Jun Li and HAA. CHEMICAL CONSTITUENTS OF Lepidium sativum SEEDS. Chem. Nat. Compd. 2019; 55(4):736-737.

107. Fan, Qing-lu; Guo, Bao-lin; Huang W. Advances in studies on chemical constituents of Lepidium sativum and its pharmacological activities. Xiandai Yaowu Yu Linchuang 2013; 28(1):90-95.

108. Abd El-Salam K, Toliba A, El-Shourbagy G, et al. CHEMICAL AND FUNCTIONAL PROPERTIES OF GARDEN CRESS (Lepidium sativum L.) SEEDS POWDER. Zagazig J. Agric. Res. Epub ahead of print 2019. DOI: 10.21608/zjar.2019.48168

109. Ahmad R, Mujeeb M, Anwar F, et al. Pharmacognostical and phytochemical analysis of Lepidium sativum L. seeds. Int. Curr. Pharm. J. Epub ahead of print 2015. DOI: 10.3329/icpj.v4i10.24913.

110. Suryawanshi JS., Gawade SP. Development and evaluation of Lepidium sativum seed oil nanoemulsion. Pharma Innov. 2018; 7(10-H):414-418.

111. Singh A., Singh SK. Phytoconstituents estimation of Lepidium sativum L. seed extract using GC-MS spectroscopy. World J. Pharm. Res. 2018 7(1):1360-1367.

112. Shukla A, Singh CS, Bigoniya P. Phytochemical and CNS activity of Lepidium sativum Linn. seeds total alkaloid. Der Pharm. Lett. 2011; 3(2):226-237.

113. Abd El-Shafeek KA. The flavonoids and biological activity of Lepidium sativum L. seeds. Bull. Fac. Pharm. (Cairo Univ. 2006; 44(1):121-126.

114. Raval N, Ravishankar B. Analgesic effect of Lepidium sativum Linn (Chandrashura) in experimental animals. AYU (An Int. Q. J. Res. Ayurveda) 2010; 31(3):371-373.

115. Elshal MF, Almalki AL, Hussein HK, et al. Synergistic antiosteoporotic effect of Lepidium sativum and alendronate in glucocorticoid-induced osteoporosis in Wistar rats. Afr. J. Tradit. Complement. Altern. Med. 2013; 10:267-273.

116. Ullah MA, Tungmunnithum D, Garros L, et al. Effect of ultraviolet-C radiation and melatonin stress on biosynthesis of antioxidant and antidiabetic metabolites produced in in vitro callus cultures of lepidium sativum L. Int. J. Mol. Sci. Epub ahead of print 2019. DOI: 10.3390/ijms20071787.

117. Arabia. HWAA;Saud. Protective Effect of Lepidium sativum L. Seeds Powder and Extract on Hypercholesterolemic Rats. J. Am. Sci. 2010; 6(11):873-879. 
118. Kaur A, Kumar R, Rani S, et al. Genetic diversity analysis of Lepidium sativum (Chandrasur) using inter simple sequence repeat (ISSR) markers. J. For. Res. 2015; 26(1):107-114.

119. Khan AU, Gilani AH. Natural Products Useful in Respiratory Disorders: Focus on Side-Effect Neutralizing Combinations. Phyther. Res. 2015; 29(9):1265-1285.

120. Rehman NU, Khan AU, Alkharfy KM, et al. Pharmacological basis for the medicinal use of Lepidium sativum in airways disorders. Evidence-based Complement. Altern. Med. Epub ahead of print 2012. DOI: 10.1155/2012/596524.

121. Baregama C., Goyal A. Phytoconstituents, pharmacological activity, and medicinal use of Lepidium sativum Linn.: a review. Asian J. Pharm. Clin. Res. 2019; 12(4):45-50.

122. Bylka W., Witkowska-Banaszczak E., Studzińska-Sroka E., Matławska I. Phytotherapy of respiratory tract diseases. Wiad. Lek. 2012; 65:124-131.

123. Saxena P. K.; Gupta, D. K.; Sharma, R. D.; Ritu, Gupta; Sharma KK. Prospects of phytocological activity of lepidium sativum: a review. Int. J. Pharm. Biol. Sci. 2015; 5(2):145-151.

124. Rawal N. A comprehensive review of Lepidium sativum linn, a traditional medicinal plant. World J. Pharm. Pharm. Sci. 2016; 5(5):1593-1601.

125. Qin Y. One kind of Chinese medicine decoction for treating infantile asthma. Faming Zhuanli Shenqing.

126. Sonawane MS., Patil AP., Sonawane RO., Ige PP., Patil PG. Lepidium sativum characteristics and as a multifaceted polymer: an overview. Indo Am. J. Pharm. Sci. 2019; 6(5):9470-9480.

127. Vohora SB, Khan MSY. Pharmacological studies on Lepidium sativum, Linn. Indian J. Physiol. Pharmacol. 1977; 21(2):118-120.

128. Juma A bin H bin A, Martin CR. Garden Cress (Lepidium sativum) Seeds in Fracture-induced Healing. In: Nuts and Seeds in Health and Disease Prevention. 2011. Epub ahead of print 2011. DOI: 10.1016/B978-0-12375688-6.10061-1.

129. Imade O, Erinfolami W, Ajadi R, et al. Effects of Lepidium sativum supplementation on growth and gonadotropins secretion in ovariectomized, estrogen-implanted rabbits. Asian Pacific J. Reprod. 2018; 7:155.

130. Mishra N, Mohammed A, Rizvi S. Efficacy of Lepidium Sativum to act as an anti-diabetic agent. Prog. Heal. Sci. 2017; 7(1):44-53.

131. Sium M, Kareru P, Keriko J, et al. Profile of Trace Elements in Selected Medicinal Plants Used for the Treatment of Diabetes in Eritrea. Sci. World J. Epub ahead of print 2016. DOI: 10.1155/2016/2752836.

132. Eddouks M. MM. Effect of Lepidium sativum L. on renal glucose reabsorption and urinary TGF-beta 1 levels in diabetic rats. Phyther. Res. 2008; 22(1):1-3.

133. Eddouks M, Maghrani M, Zeggwagh NA, et al. Study of the hypoglycaemic activity of Lepidium sativum L. aqueous extract in normal and diabetic rats. J. Ethnopharmacol. 2005; 97(2):391-395.

134. Tahraoui A, El-Hilaly J, Israili ZH, et al. Ethnopharmacological survey of plants used in the traditional treatment of hypertension and diabetes in south-eastern Morocco (Errachidia province). J. Ethnopharmacol. 2007; 110(1):105-117.

135. Peng, Changan; Peng C. Processing method of cress beverage. Faming Zhuanli Shenqing.

136. Prajapati VD, Maheriya PM, Jani GK, et al. Lepidium sativum Linn.: A current addition to the family of mucilage and its applications. Int. J. Biol. Macromol. 2014; 65:72-80.

137. Ibarra AAG, Wrobel K, Escobosa ARC, Elguera JCT, Garay-Sevilla ME, Wrobel K. Determination of putrescine, cadaverine, spermidine and spermine in different chemical matrices by high performance liquid chromatography-electrospray ionization-ion trap tandem mass spectrometry (HPLC-ESIITMS/MS). J. Chromatogr. B Anal. Technol. Biomed. Life Sci. 2015; 1002:176-184.

138. El-Dakak AMNH, Abd El-Rahman HSM, El-Nahal DMM. Comparison studies between aqueous lepidium sativum L., lupinus albus and trigonella foenum-gracum seeds, and their mixture extracts on streptozotocininduced diabetic rats. J. Appl. Sci. Res. 2013; 9(4):2965-2982.
139. Wrobel K, Gómez Ojeda A, Corrales Escobosa AR, et al. Effect of Cd(ii) and Se(iv) exposure on cellular distribution of both elements and concentration levels of glyoxal and methylglyoxal in Lepidium sativum. Metallomics 2013; 5(9):1254-1261.

140. Naik A, Meda V, Lele SS. Freeze drying for microencapsulation of $\alpha$ linolenic acid rich oil: A functional ingredient from Lepidium sativum seeds. Eur. J. Lipid Sci. Technol. 2014; 116(7):837-846.

141. Umesha SS, Monahar B, Naidu AA. Microencapsulation of $\alpha$-linolenic acidrich garden cress seed oil: Physical characteristics and oxidative stability. Eur. J. Lipid Sci. Technol. 2013; 115(12):1474-1482.

142. PW J. Lepidium sativum Effects on Reproduction and Visceral Organ Development in Sprague-Dawley Rats Culminating Projects in Biology. College of Science and Engineering, 2017.

143. Yadav YC, Srivastav DN, Seth AK, et al. Nephroprotective and curative activity of Lepidium sativum L. seeds in albino rats using cisplatin induced nephrotoxicity. Pharma Chem. 2009; 2(4):57-64.

144. Alwakeel SS. The Effect of Mycotoxins found in some Herbal Plants on Biochemical Parameters in Blood of Female Albino Mice. Pakistan J. Biol. Sci. 2009; 12(8):637-642.

145. Yadav YC, Srivastav DN, Seth AK, et al. In vivo antioxidant potential of lepidium sativum I. Seeds in albino rats using cisplatin induced nephrotoxicity. Int. J. Phytomedicine 2010; 2:292-298.

\section{HOW TO CITE THIS ARTICLE}

Shah MB, Dudhat VA, Gadhvi KV. Lepidium sativum: A potential functional food. J Ayu Herb Med 2021;7(2):140-149. DOI: 10.31254/jahm.2021.7213

Creative Commons (CC) License-

This article is an open access article distributed under the terms and conditions of the Creative Commons Attribution (CC BY 4.0) license. This license permits unrestricted use, distribution, and reproduction in any medium, provided the original author and source are credited. (http://creativecommons.org/licenses/by/4.0/) 